\title{
Techniki rejestracji zdalnej w kartowaniu geomorfologicznym wybrzeży klifowych
}

\author{
Remote sensing techniques in geomorphological mapping of cliff coasts
}

\author{
Marcin Winowski ๑ \\ Instytut Geoekologii i Geoinformacji, Uniwersytet im. Adama Mickiewicza w Poznaniu, marwin@amu.edu.pl
}

\begin{abstract}
Zarys treści: W artykule przedstawiono ocenę trzech technik rejestracji zdalnej wykorzystywanej w kartowaniu geomorfologicznym wybrzeży klifowych. Analizie poddano podstawowe parametry chmur punktów pozyskanych w procesie lotniczego skanowania laserowego $(A L S)$, naziemnego skanowania laserowego (TLS) oraz cyfrowego przetwarzania zdjeć pozyskanych za pomocą drona (Structure from Motion - UAV-SfM). Uzyskane wyniki pozwoliły stwierdzić, iż modele o najwyższej rozdzielczości i największej dokładności można uzyskać wykorzystując techniki TLS oraz UAV-SfM. Te dwie techniki dają największe możliwości w szczegółowych analizach rzeźby oraz szacowaniu bilansu osadów na niewielkich poligonach badawczych. Mniejszą dokładnością charakteryzują się zobrazowania ALS, jednak do badań prowadzonych na większych obszarach wydają się być najbardziej optymalnym rozwiązaniem.
\end{abstract}

Słowa kluczowe: teledetekcja, ALS, TLS, UAV-SfM, monitoring geomorfologiczny, wybrzeża klifowe

\begin{abstract}
This paper presents the evaluation of three remote sensing methods used in geomorphological mapping of cliff coasts. The basic parameters of point clouds obtained in the process of airborne laser scanning (ALS), terrestrial laser scanning (TLS) and digital processing of photos obtained with UAV (Structure from Motion - UAV-SfM) were analysed. The obtained results allowed to state that the models with the highest resolution and accuracy can be obtained using the TLS and UAV-SfM methods. These two techniques provide the greatest possibilities in detailed relief analyses and estimation of the sediment budget in small research sites. Images of ALS are less accurate, but for studies carried out in larger areas they seem to be the most optimal solution.
\end{abstract}

Key words: remote sensing, ALS, TLS, UAV-SfM, geomorphological mapping, cliff coast

\section{Wstęp}

Wybrzeża morskie wykazują dużą czułość na zmiany klimatyczne. Wraz ze zwiększającą się częstotliwością spiętrzeń sztormowych brzegi klifowe oraz wydmowe podlegają wzmożonej erozji. Sytuacja taka niekorzystnie wpływa na bezpieczeństwo ludności zamieszkującej strefy nadmorskie. Zachodzące zmiany rzeźby mają najczęściej charakter gwałtowny, a ich rozmiar warunkowany jest przede wszystkim natężeniem głównego czynnika niszczącego, jakim są spiętrzenia sztormowe. W zarządzaniu morską strefą brzegową niezwykle ważne jest prowadzenie systematycznego monitoringu geomorfologicznego, który daje możliwość szybkiej identyfikacji obszarów poddawanych silnej erozji. Zebrane informacje stanowią podstawę planowania zabiegów ochronnych, które zgodne są z założeniami zrównoważonego rozwoju.

Postępujący rozwój technologiczny umożliwia wykorzystanie coraz dokładniejszych technik pomiarowych, które $\mathrm{w}$ badaniach naukowych odgrywają kluczową rolę. Aktualnie wśród najszybciej rozwijających się metod obserwacji środowiska geograficznego należy wyróżnić teledetekcję, czyli metodę, za pomocą której informacje pozyskiwane są w sposób zdalny bez ingerencji w obserwowany obiekt. Samo pojęcie teledetekcji odnosi się do grupy technik gromadzenia danych o oddalonym obiekcie na podstawie analizy fal elektromagnetycznych emitowanych lub odbitych od tego obiektu (Bęcek 2010). Wykonywanie pomiarów odbywa się za pomocą sensorów, których rolę najczęściej odgrywają specjalistyczne 
kamery lub skanery. Obrazowanie powierzchni Ziemi może być wykonywane w sposób pasywny (sensor rejestruje charakterystykę promieniowania odbitego, które pierwotnie emitowane jest przez słońce - produktem są obrazy panchromatyczne i multispektralne) lub w sposób aktywny (nadajnik wysyła sygnał, a odbiornik rejestruje wiązkę odbitą i analizuje jej charakterystykę - rezultatem są obrazy radarowe, sonarowe czy lidarowe). Pomiary mogą odbywać się na platformach naziemnych (np. naziemny skaning laserowy - TLS) lub powietrznych (na różnych pułapach: lotniczy $<12 \mathrm{~km}$; satelitarny $>200 \mathrm{~km}$ ). Uzyskane tę metodą obrazy poddawane są następnie odpowiedniej obróbce i interpretacji.

Dla celów monitoringu geomorfologicznego wybrzeży morskich najczęściej wykorzystywane są techniki obrazowania fotogrametrycznego oraz lidarowego (skanowania laserowego) (Kolander i in. 2013, Dudzińska-Nowak, Wężyk 2014, Dudzińska-Nowak 2017, Frydel i in, 2017, Winowski, Śramski 2017, Terefenko i in. 2018, 2019, Uścinowicz i in. 2019). W badaniach wybrzeży morskich aktualnie największym uznaniem cieszą się techniki naziemnego i lotniczego skanowania laserowego. Będące rezultatem tych technik wielomilionowe chmury punktów bardzo dokładnie odwzorowują rzeźbę terenu. W ostatnich latach bardzo dobrze rozwinęła się technologia bezzałogowych statków powietrznych. Technologia ta daje nieocenione możliwości dla potrzeb monitoringu przyrodniczego. W krótkim czasie możliwe jest pozyskanie serii zdjęć badanego obiektu i przy odpo- wiednim wykorzystaniu techniki fotogrametrycznej Structure from Motion dokładnego odwzorowania jego geometrii (Westboy i in. 2012).

$\mathrm{Na}$ wybrzeżu klifowym wyspy Wolin od roku 1973 prowadzone są systematyczne badania morfodynamiki klifu, których celem jest ocena funkcjonowania systemu denudacyjnego (Kostrzewski, Zwoliński 1994a, b, 1995). Od 1984 roku wykonywane są zorganizowane pomiary tempa cofania korony klifu na pięciu odcinkach testowych (Kostrzewski, Zwoliński 1994a, b, 2012, Kostrzewski i in 2015, Winowski i in. 2019). Zastosowane do tego celu tradycyjne domiary taśmą mierniczą do reperów są metodą, która obrazuje przemieszczanie korony klifu tylko w wyznaczonych transektach. Niestety nie umożliwia ona rozpoznania zmian rzeźby zachodzących na całym skłonie klifu. Te braki mogą być uzupełnione przez zastosowanie metody rejestracji zdalnej.

Celem niniejszego artykułu jest przybliżenie możliwości nowoczesnych technik rejestracji zdalnej dla potrzeb monitoringu geomorfologicznego wybrzeży klifowych w oparciu o własne pomiary terenowe oraz dane pozyskane z zasobów Urzędu Morskiego w Szczecinie.

\section{Metodyka}

W artykule zostały opisane trzy techniki obrazowania klifów, opierające się $\mathrm{w}$ dwóch przypadkach na
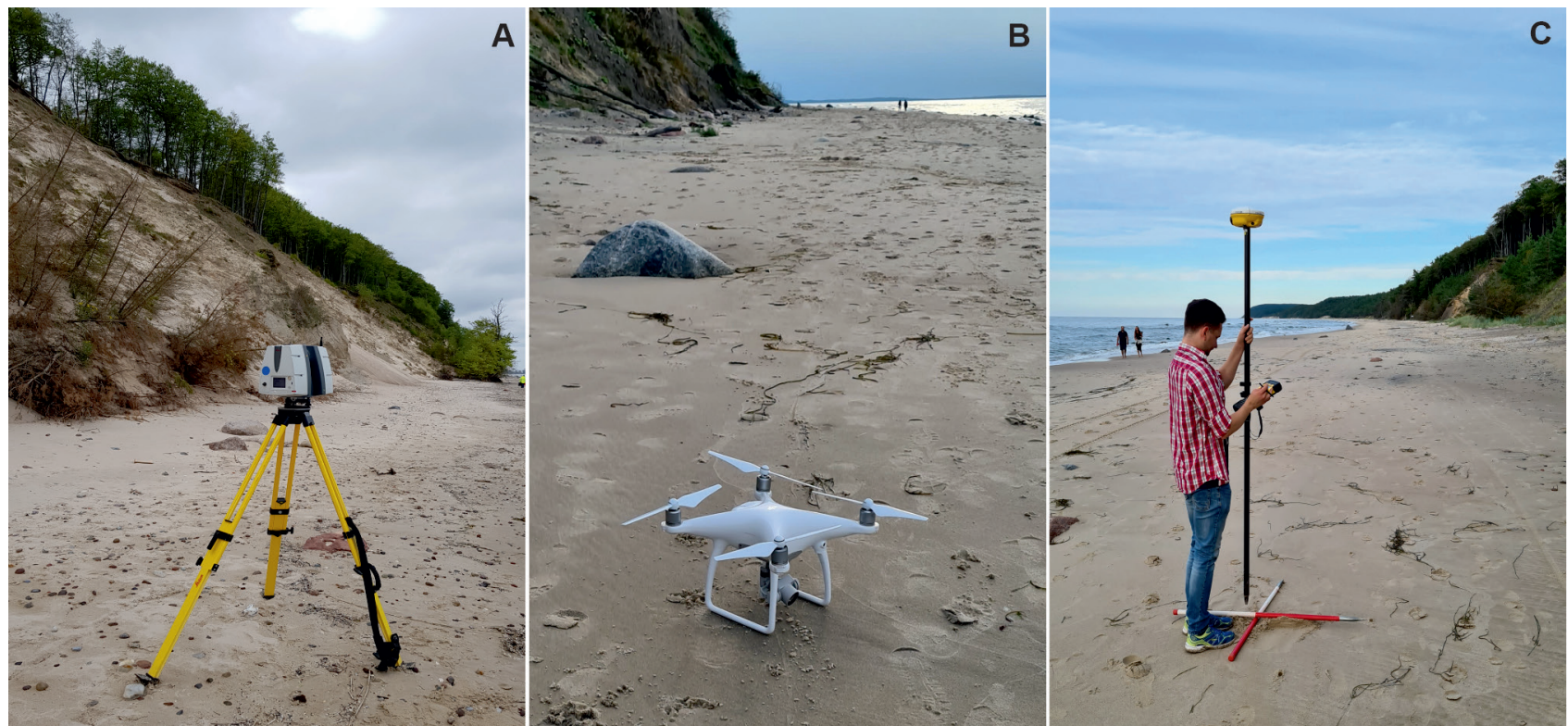

Ryc. 1. Sprzęt pomiarowy wykorzystany do badań

A - skaner laserowy Leica ScanStation c10, B - dron DJI Phantom 4 wykorzystany do pozyskania zdjęć wybrzeża klifowego, C - odbiornik GPS RTK Trimble SPS 882 wykorzystany do pomiarów naziemnych punktów kontrolnych (GCP)

Fig. 1. Measuring equipment used for research

A - Leica ScanStation c10 laser scanner, B - DJI Phantom 4 UAV used to acquire photos of the cliff coast, C - the GPS RTK Trimble SPS 882 receiver used to measure ground control points $(G C P)$ positions 
skanowaniu laserowym: lotniczym skaningu laserowym (ang. airborne laser scanning, $A L S$ ) i naziemnym skaningu laserowym (ang. terrestrial laser scanning, $T L S)$ i w jednym przypadku na technice cyfrowego przetwarzania zdjęć (ang. Structure from Motion, SfM) pozyskanych za pomocą bezzałogowego statku powietrznego $(U A V)$.

Dane $z$ lotniczego skaningu laserowego udostępnione zostały przez Urząd Morski w Szczecinie. Natomiast dane pochodzące $z$ naziemnego skanowania laserowego pozyskane zostały w trakcie badań terenowych. Prace wykonane zostały przy wykorzystaniu skanera laserowego firmy Leica ScanStation c10. Jest to skaner impulsowy o maksymalnej szybkości skanowania $50000 \mathrm{pkt} \mathrm{s}^{-1}$, gdzie błąd pomiaru pojedynczego punktu ma charakter systematyczny i kształtuje się na poziomie $4 \mathrm{~mm} / 50 \mathrm{~m}$ (ryc. 1).

Kartowanie wybrzeża klifowego wyspy Wolin wykonane zostało za pomocą bezzałogowego statku powietrznego firmy DJI Phantom 4, na pokładzie którego seryjnie montowane są kamery DJI FC330 z matrycą CMOS 1/2,3" o rozdzielczości 12 Mpix i jasności obiektywu F/2,8 (dla formatu $35 \mathrm{~mm}$ ) (ryc. 1). Dzięki takiemu zestawowi możliwe jest pozyskanie obrazów wysokiej jakości. W celu przeprowadzenia optymalizacji kamery mającej na celu zwiększenie dokładności przestrzennej tworzonego modelu, wykorzystano 12 punktów kontroli naziemnej (ang. Ground Control Point, GCP). Pozycja GCPs pomierzona została za pomocą odbiornika GPS RTK Trimble SPS 882 (ryc. 1). Zastosowane oprogramowanie Agi-
Soft Photoscan umożliwiło stworzenie gęstej chmury punktów oraz wyliczenie średniego błędu kwadratowego (RMSE) dla każdego punktu kontrolnego. Wizualizacja chmur punktów oraz podstawowe statystyki dotyczące liczby punktów, średniej odległości między punktami, gęstości powierzchniowej oraz jej rozkładu przestrzennego zostały wykonane $\mathrm{w}$ programach Cloudcompare oraz ArcMap.

Wszystkie pomiary zostały wykonane w 2018 roku, przy czym naziemne skanowanie laserowe odbyło się na początku sezonu wiosennego wraz z rozpoczęciem wegetacji roślinnej (08.05.2018 r.). Z kolei lotniczy skaning laserowy przeprowadzony został pod koniec sezonu letniego w dniu 09.09.2018 r., natomiast zdjęcia do analizy fotogrametrycznej (SfM) pozyskano za pomocą drona (UAV) w środku sezonu jesiennego w dniu 17.11.2018 r. Brak czasowej zgodności wykonanych pomiarów nie stanowi problemu dla poniższego opracowania, ponieważ $\mathrm{w}$ ramach badań nie koncentrowano się na analizie stanu rzeźby, ale na ocenie konkretnych parametrów otrzymanych wyników.

\section{Obszar badań}

Monitoring geomorfologiczny prowadzony jest na wybrzeżu klifowym wyspy Wolin w pasie rozciągającym się pomiędzy Grodnem (406,3 km UM) a Białą Górą (410,1 km UM) (ryc. 2). Na odcinku tym od połowy

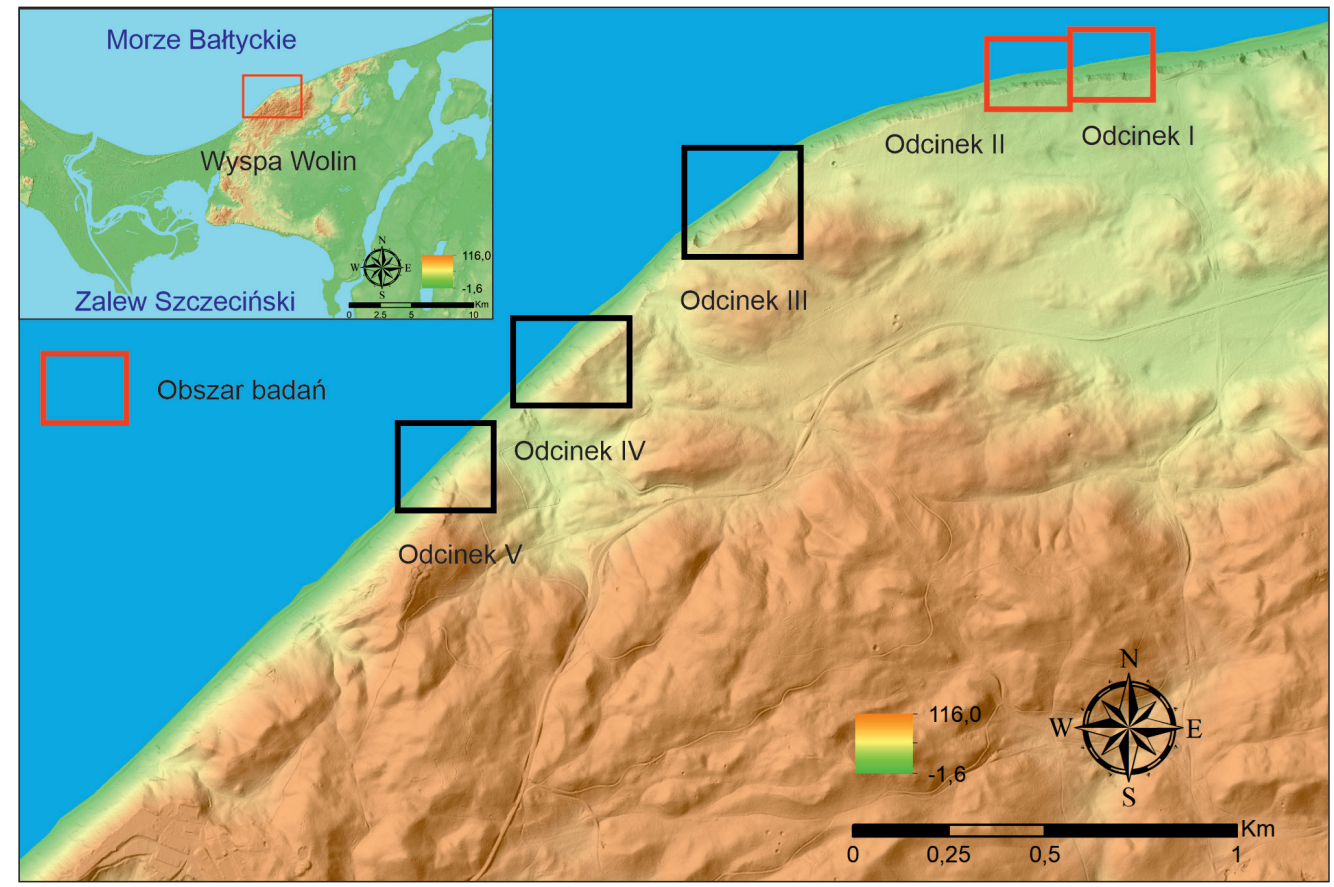

Ryc. 2. Lokalizacja odcinków testowych wybrzeża klifowego poddanych monitoringowi geomorfologicznemu od roku 1974. Czerwonym kolorem zaznaczono odcinki omawiane w artykule

Fig. 2. Location of test sections of the cliff coast where geomorphological monitoring has been carried out since 1974. The sections discussed in the paper are marked in red 


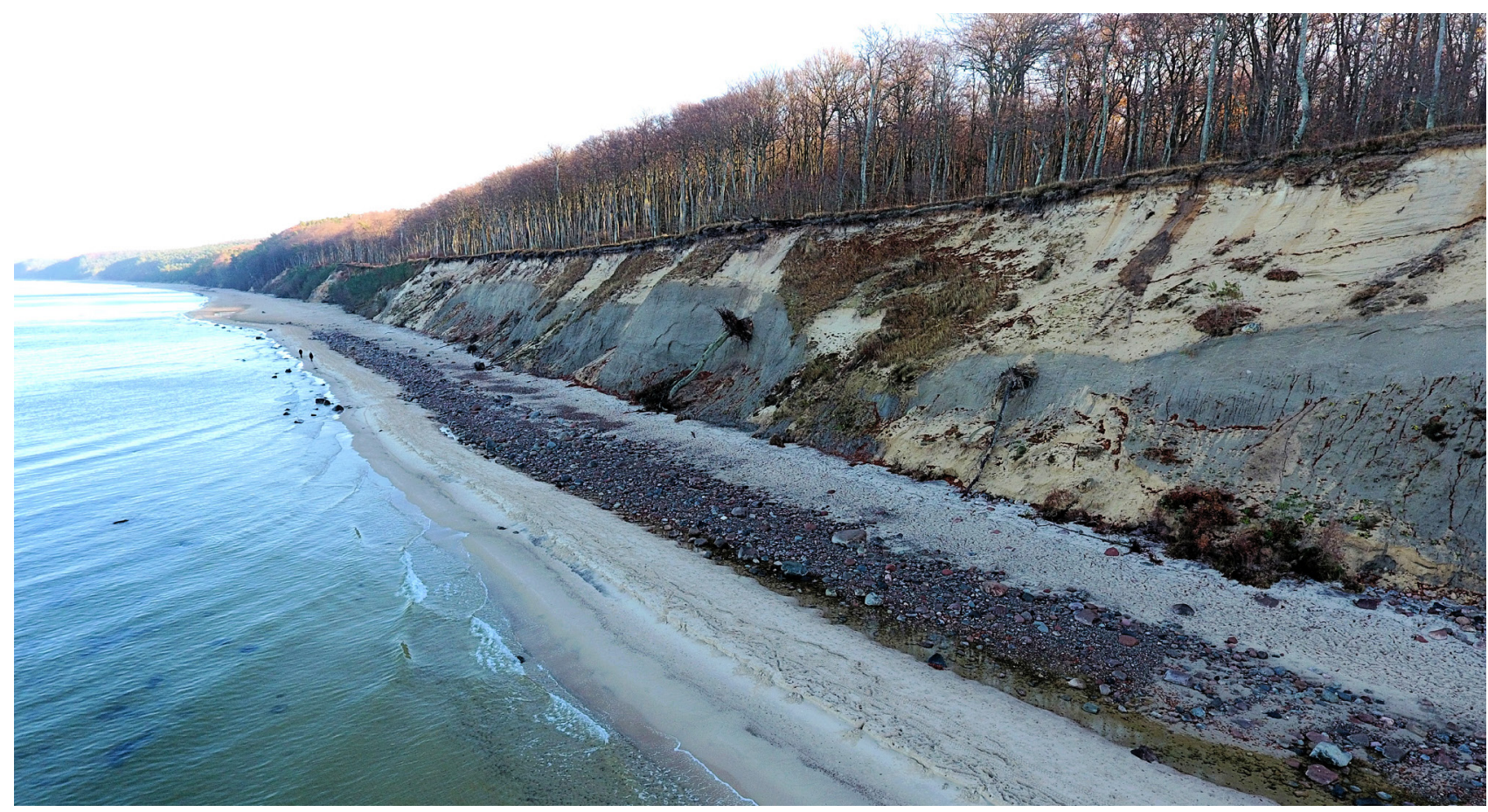

Ryc. 3. Fotografia przedstawiająca charakterystyczny układ warstw litologicznych klifu: kolorem jasnym zaznaczają się serie piaszczyste i koluwialne, zaś kolorem szarym - pokłady gliny morenowej

Fig. 3. The photograph shows the characteristic lithological layers of the cliff: the sandy and coluvial series are marked with a light color, while the layers of moraine clay are marked in gray

lat 70-tych systematycznie prowadzone są obserwacje morfodynamiki klifu (Kostrzewski, Zwoliński 1986), przy czym badania ilościowe oparte o system reperów zapoczątkowane zostały w 1984 roku (Kostrzewski, Zwoliński 1994b, 2012). Pomiary te odbywają się na pięciu reprezentatywnych odcinkach charakteryzujących się zróżnicowaną morfologią, morfometrią, budową geologiczną oraz dynamiką (Kostrzewski $\mathrm{i}$ in. 2015). Na potrzeby niniejszego artykułu prezentowane są materiały dotyczące dwóch pierwszych odcinków leżących we wschodniej części wybrzeża, nieopodal Grodna (406,85-407,25 km UM) (ryc. 2). Dane prezentują ukształtowanie wybrzeża o długości $385 \mathrm{~m} \mathrm{w}$ pasie rozciągającym się między linią wody, a koroną klifu. Dzięki temu możliwe było zobrazowanie powierzchni plaży oraz stoku klifu.

Analizowany odcinek klifu jest najniższym spośród wszystkich monitorowanych. Jego maksymalna wysokość wynosi 26,5 m n.p.m., zaś minimalna 17,7 m n.p.m. W budowie geologicznej klifu występują trzy zasadnicze serie osadowe: glina zwałowa, piaski fluwioglacjalne oraz eoliczne piaski pokrywowe $z$ zaznaczonymi poziomami gleb kopalnych (Kostrzewski 1985, Borówka i in. 1982, 1999) (ryc. 3). Poszczególne typy osadów charakteryzują się zmienną odpornością na procesy denudacyjne. Nachylenie stoku jest wyższe $\mathrm{w}$ części zbudowanej z osadów spoistych (max: $88^{\circ}$ ), natomiast górne partie stoków zbudowane $z$ osadów piaszczystych oraz dolne $z$ redeponowanych osadów koluwialnych charakteryzują się nieco niższym spadkiem, zawierającym się w granicach $30-40^{\circ}$. Klif w części piaszczystej w niewielkim stopniu porośnięty jest roślinnością trawiastą i miejscami młodnikiem sosnowym.

\section{Rejestracja zdalna w monitoringu geomorfologicznym klifów}

W monitoringu geomorfologicznym klifów wolińskich testowane są różne metody pozyskiwania informacji dotyczących stanu rzeźby oraz jej czasowych zmian. Wśród nieinwazyjnych metod pomiarowych najbardziej efektywnymi są te, które bazują na rejestracji zdalnej. Głównym celem stosowanych metod jest uzyskanie chmur punktów, na podstawie których tworzone są cyfrowy model wysokościowy (CMW) i numeryczny model pokrycia terenu (NMPT).

Skaning laserowy już od prawie dwóch dekad jest uznaną techniką pomiarową wykorzystywaną w nauce, leśnictwie, budownictwie, architekturze etc. (Hyg, Wehr 1997, Gomes Pereira, Wicherson 1999, Reutebuch i in. 2003, Wężyk 2006). Jej szerokie zastosowanie wynika ze znacznej automatyzacji wykonywanych pomiarów oraz dużej dokładności uzyskiwanych wyników. Technika ta polega na zdalnym pozyskiwaniu informacji o przestrzennej lokalizacji i geometrii interesującego obiektu. W pomiarach wykorzystuje się skoncentrowaną wiązkę promienio- 
wania elekromagnetycznego, najczęściej w zakresie bliskiej podczerwieni (laser). Wiązka emitowana jest w kierunku obiektu, która następnie po dotarciu do niego odbija się i powraca do detektora (Wężyk 2006, Stereńczak 2009, Kurczyński 2014, Głowienka i in. 2015). Zintegrowany komputer analizując czas, który upłynął od momentu wysłania wiązki do jej powrotu oraz kąta pod jakim została wysłana jest w stanie precyzyjnie wyznaczyć współrzędne przestrzenne XYZ pomierzonego punktu. Zastosowanie w skanerze systemu wirujaccych luster umożliwia wyemitowanie w jednej sekundzie dziesiątek lub setek tysięcy promieni. Dzięki temu w krótkim czasie powstaje wielomilionowa chmura punktów (Wężyk 2006).

Podstawową zaletą skaningu laserowego jest możliwość stosowania go na wielu platformach. Ska-

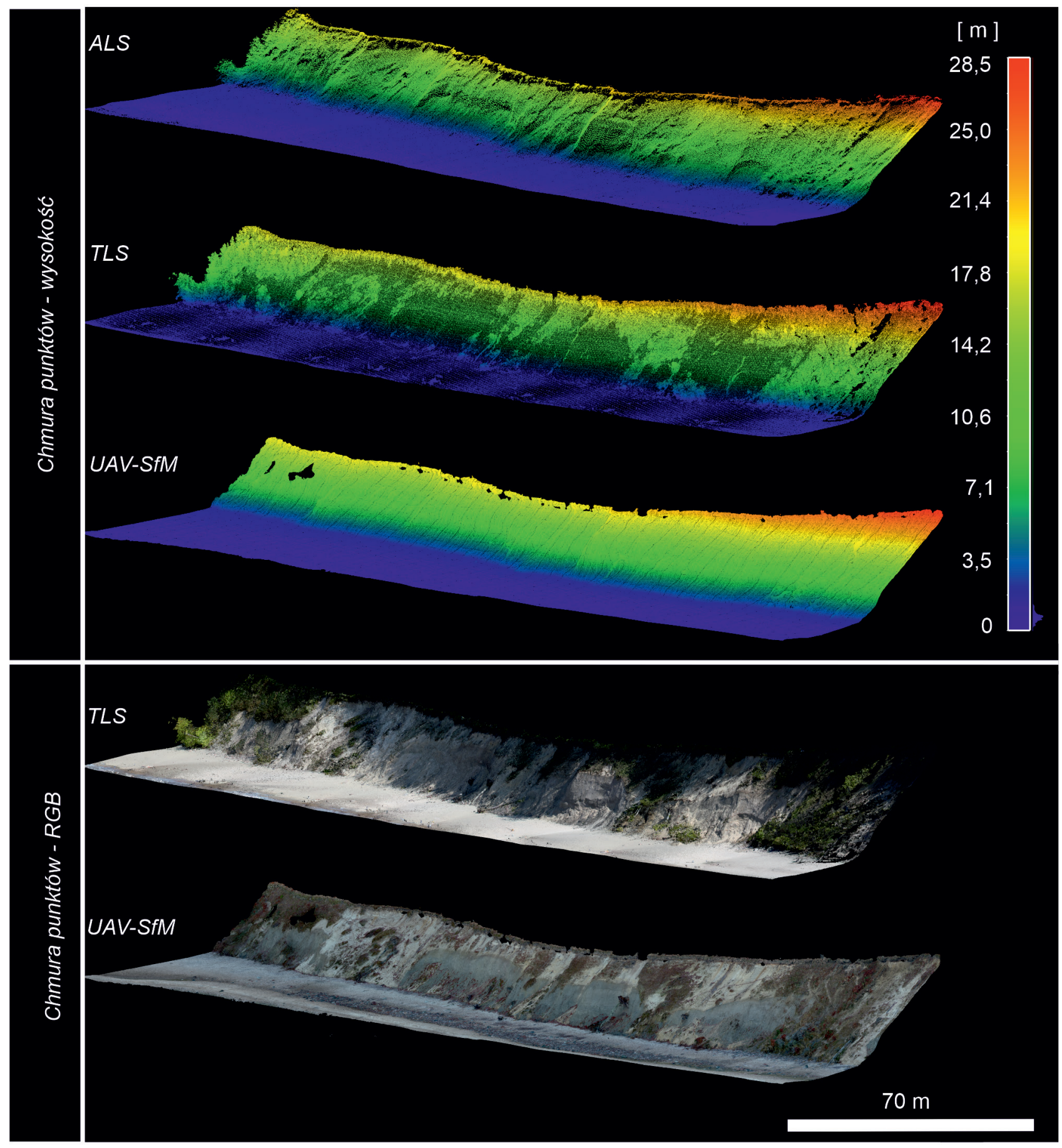

Ryc. 4. Chmury punktów będące efektem zastosowania różnych technik rejestracji zdalnej (ALS, TLS, UAV-SfM). W górnej części wizualizacja została oparta o wartości wysokości, zaś w dolnej o barwy RGB (tylko dla TLS i UAV-SfM)

Fig. 4. Point clouds as a result of use of various remote registration methods ( $A L S, T L S, U A V$-SfM). In the upper part, the visualization was based on the height values, and in the lower part - RGB colors (only for TLS and UAV-SfM) 
nowanie laserowe dzieli się na cztery zasadnicze grupy: SLS - Satellite Laser Scanning, ALS - Airborne Laser Scanning, MLS - Mobile Laser Scanning, TLS - Terrestrial Laser Scanning.

Lotniczy skaning laserowy wykorzystywany jest przez Urzędy Morskie od 2008 roku przede wszystkim w celu inwentaryzacji oraz monitoringu pasa technicznego wybrzeża. Pomiarami objęty jest pas lądu o szerokości $500 \mathrm{~m}$ od linii wody. Z przeprowadzonego pomiaru uzyskiwana jest gęsta chmura punktów (dense cloud) w układzie współrzędnych WGS-84 przeliczonym do układu PUWG 1992 (ryc. 4). Każdy punkt chmury posiada zasadnicze informacje dotyczące położenia $\mathrm{w}$ przestrzeni geograficznej $\mathrm{XYZ}$, intensywności odbicia, numeru odbicia, liczby odbić, kierunku skanowania etc. Stosowane w systemie ALS specjalistyczne skanery rejestrują kilka odbić (ech) pojedynczego impulsu laserowego. Pierwsze echo pochodzi z pierwszej napotkanej przeszkody. W przypadku obszarów zadrzewionych jest to korona drzew. Natomiast ostatnie echo przypada najczęściej na powierzchnię gruntu. Pomiędzy skrajnymi odbiciami mogą pojawiać się echa pośrednie, które charakteryzują takie obiekty jak np. roślinność niska lub średnia. Przedstawiona struktura danych umożliwia ich klasyfikację. Proces ten polega na przypisaniu punktów do kategorii obiektów, od których się odbiły (np. grunt, roślinność niska, średnia, wysoka, budynki, obiekty inżynierskie itd.). Sklasyfikowane chmury punktów umożliwiają z kolei stworzenie modelu pokrycia terenu, czyli rastrowego modelu, który reprezentuje powierzchnię terenu wraz z obiektami na niej występującymi (budynki, roślinność, mosty itd.). Model taki tworzy się na podstawie punktów pochodzących z pierwszego odbicia (echa). Wykorzystanie punktów z ostatniego odbicia umożliwia $z$ kolei stworzenie cyfrowego modelu wysokościowego (Wężyk 2006, 2015). W monitoringu geomorfologicznym wybrzeży morskich najczęściej wykorzystuje się cyfrowe modele wysokościowe gdyż to one przedstawiają rzeczywistą konfigurację rzeźby. Dobór najwyższej rozdzielczości cyfrowego modelu wysokościowego warunkowany jest gęstością chmury punktów. W literaturze przyjmuje się, że liczba komórek siatki powinna być $\mathrm{w}$ przybliżeniu równa liczbie zeskanowanych punktów na danym obsza- rze. Rozmiar siatki CMW powinien zatem odpowiadać średniemu odstępowi między punktami chmury (Macullagh 1988, Liu i in. 2007). Tę wartość można wyliczyć na podstawie poniższego wzoru:

$$
S=\sqrt{\frac{A}{n}}
$$

gdzie:

- A - powierzchnia skanowanego obszaru $\left[\mathrm{m}^{2}\right]$,

- $n$ - liczba punktów w chmurze.

$\mathrm{Na}$ prezentowanym odcinku wybrzeża klifowego analizowaną chmurę ALS z 2018 roku tworzy 601 405 punktów. Średnia gęstość chmury wynosi 28 pkt $\mathrm{m}^{-2} \mathrm{~W}$ zakresie od 0-62 pkt $\mathrm{m}^{-2}$ (ryc. 5, tab. 1). Jest to wartość kilkukrotnie wyższa od chmury punktów uzyskanej w projekcie ISOK $^{1}$ z 2011 roku, tj. 4 pkt $\mathrm{m}^{-2}$. Analizowana $\mathrm{w}$ artykule gęstość chmury odnosi się do punktów z pierwszego echa. Zróżnicowanie gęstości powierzchniowej w skaningu lotniczym zależy w głównej mierze od nachylenia terenu. Największą koncentrację punktów obserwuje się na obszarach płaskich (plaże), zaś najniższą na stokach mocno nachylonych (klify gliniaste) (ryc. 5). Średnia odległość między punktami chmury na analizowanym obszarze wynosi $0,17 \mathrm{~m}$, co daje możliwość wygenerowania NMPT o rozdzielczości ok. 0,17 m. W przypadku chmury punktów przypisanych do kategorii grunt (78\% wszystkich punktów) rozdzielczość cyfrowego modelu wysokościowego będzie odpowiednio niższa. Dokładność położenia punktów $\mathrm{w}$ chmurze wynosi RMSE $=0,2 \mathrm{~m}$ (tab. 1).

W przypadku naziemnego skaningu laserowego TLS technologia obrazowania polega na podobnej zasadzie, co $A L S$, przy czym jednostka skanująca montowana jest na statywie geodezyjnym. Naziemne skanery laserowe charakteryzują się o wiele mniej-

\footnotetext{
ISOK - Informatyczny System Osłony Kraju przed nadzwyczajnymi zagrożeniami. Zasadniczym celem projektu jest stworzenie jednolitego systemu informatycznego poprawiającego osłonę społeczeństwa i gospodarki przed nadzwyczajnymi zagrożeniami. Jednym $z$ efektów wdrożonego systemu jest numeryczny model terenu i numeryczny model pokrycia terenu dla obszaru całego kraju, który bazuje na danych z lotniczego skaningu laserowego. Dla wybrzeża morskiego wyspy Wolin nalot taki został wykonany raz w 2011 roku. Od 2020 r. dane te są ogólnodostępne i można je pobrać $z$ serwisu www.geoportal.gov.pl.
}

Tabela 1. Podstawowe parametry uzyskanych chmur punktów

Table 1. Basic parameters of the obtained point clouds

\begin{tabular}{|c|c|c|c|c|}
\hline $\begin{array}{l}\text { Parametr } \\
\text { Parameter }\end{array}$ & $\begin{array}{c}\text { Jednostka } \\
\text { Unit }\end{array}$ & ALS & TLS & SfM \\
\hline Liczba punktów & - & 601405 & 109624825 & 22170884 \\
\hline Średnia gęstość & pkt $\mathrm{m}^{-2}$ & 28 & 35634 & 1033 \\
\hline Średni odstęp miedzy punktami & $\mathrm{m}$ & 0,17 & 0,013 & 0,029 \\
\hline Błąd pomiaru (RMSE) & $\mathrm{m}$ & 0,20 & 0,014 & 0,044 \\
\hline Rozmiar pliku & MB & 25 & 2700 & 550 \\
\hline
\end{tabular}



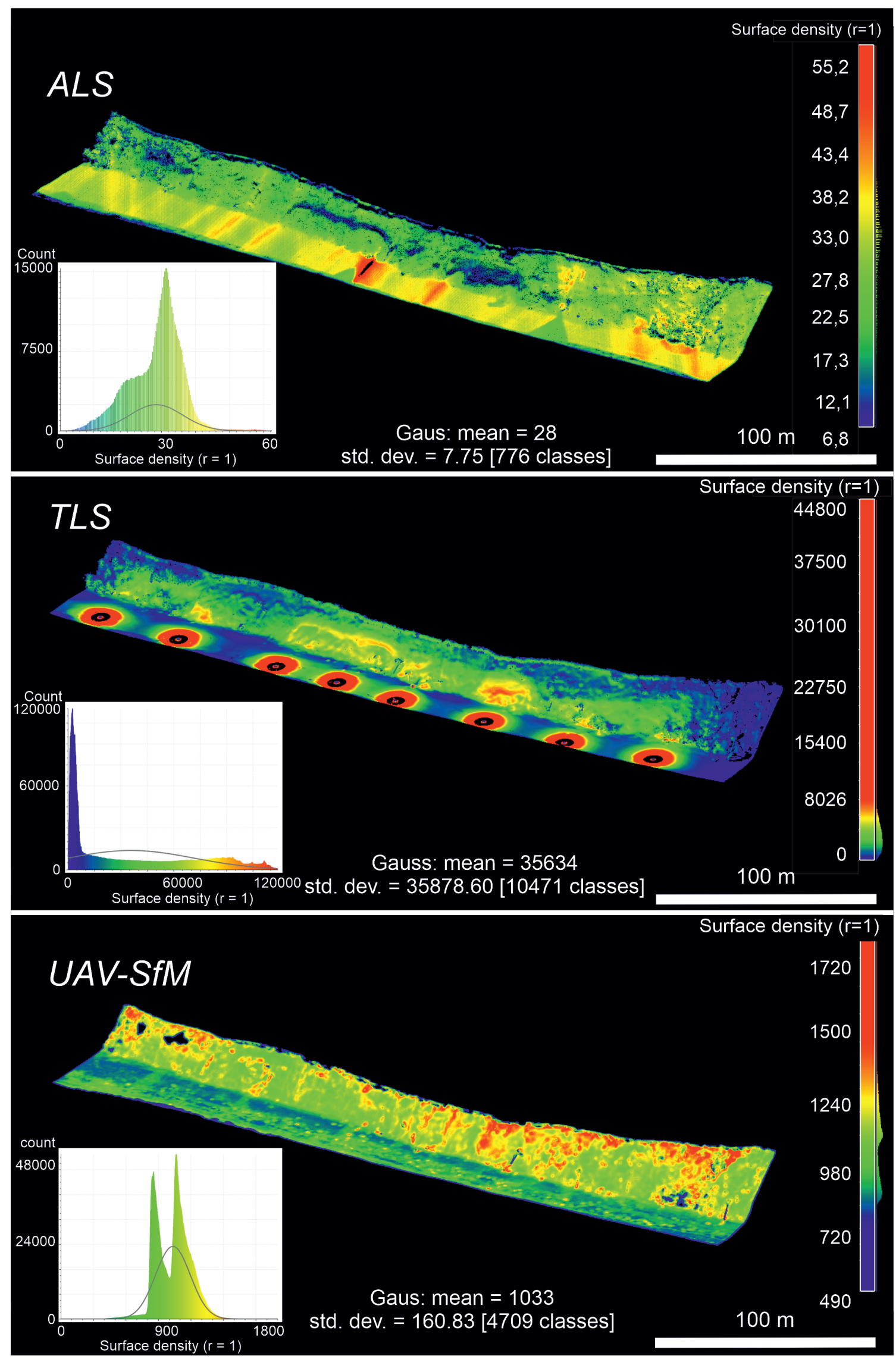

Ryc. 5. Wizualizacja gęstości powierzchniowej uzyskanych chmur punktów

Fig. 5. Visualization of surface density of the obtained point clouds 
szym zasięgiem skanowania od skanerów lotniczych. Wykorzystany dla potrzeb monitoringu skaner Leica ScanStation c10 charakteryzuje się maksymalnym zasięgiem skanowania $\mathrm{w}$ zakresie od $134 \mathrm{~m}$ (przy $18 \%$ albedo) do $300 \mathrm{~m}$ (90\% albedo), dlatego też w celu skartowania większego obszaru wymagane jest założenie odpowiedniej liczby stanowisk pomiarowych. Naziemny skaning laserowy umożliwia pozyskanie obrazów o bardzo wysokiej rozdzielczości. Gęstość wiązki lasera można ustawić w aparaturze przed rozpoczęciem pomiaru. Parametr ten definiuje się $\mathrm{w}$ zależności od specyfiki prowadzonych badań. W celu uzyskania dużej szczegółowości niewielkich obiektów wymagana jest duża gęstość chmury punktów. Równie ważnym parametrem uwzględnianym w skaningu laserowym jest dokładność pomiaru, która w decydującym stopniu wpływa na wiarygodność uzyskiwanych wyników. W przypadku stosowanego skanera Leica ScanStation C10 systematyczny błąd pomiaru wynosi $4 \mathrm{~mm} / 50 \mathrm{~m}$. Oznacza to, iż na każde $50 \mathrm{~m}$ odległości błąd pomiaru zwiększa się o $4 \mathrm{~mm}$. W przypadku skanowanego klifu średni błąd kwadratowy uzyskanej chmury punktów (RMSE) wyniósł 0,014 m (tab. 1). Dodatkowym akcesorium często stosowanym $\mathrm{w}$ naziemnym skaningu laserowym są zintegrowane wysokorozdzielcze aparaty cyfrowe, które rejestrują obraz skanowanej przestrzeni w zakresie promieniowania widzialnego, najczęściej według modelu graficznego RGB. Dzięki temu możliwe jest zobrazowanie chmury punktów $\mathrm{w}$ barwach rzeczywistych (ryc. 4).

Przeprowadzone skanowanie laserowe TLS wybrzeża klifowego wyspy Wolin umożliwiło uzyskanie wielomilionowej chmury punktów (ryc. 4). W przypadku analizowanego odcinka na utworzoną chmurę przypadało 109624825 punktów. Średnie zagęszczenie chmury wyniosło $35634 \mathrm{pkt} \mathrm{m}^{-2} \mathrm{w}$ zakresie od 1 pkt m-2 do 119000 pkt m${ }^{-2}$ (ryc. 5, tab. 1). Tak duże zróżnicowanie przestrzenne zagęszczenia punktów wynika ze specyfiki skanowania laserowego. Skaner wysyła wiązki lasera pod ustalonym kątem i w związku z tym zagęszczenie punktów spada wraz $z$ oddalaniem się skanowanej powierzchni. W przypadku przeprowadzonego pomiaru rozdzielczość skanowania wynosiła $5 \mathrm{~cm}$ na $100 \mathrm{~m}$. Oznacza to, iż na każde 100 m oddalenia obiektu odległość między pomierzonymi punktami wzrasta o $5 \mathrm{~cm}$. Ponadto na stanowisku pomiarowym skaner instalowany jest zazwyczaj na plaży na wysokości 1,5-2 m. W przypadku skanowania wysokich obiektów o zróżnicowanej geometrii jakimi są klify często dochodzi do tworzenia się martwych pól. Obszary te najczęściej powstają w efekcie wzajemnego przesłaniania się skanowanych obiektów. W celu ograniczenia tego zjawiska wymagana jest precyzyjna ocena konfiguracji terenu jeszcze przed rozpoczęciem pomiaru i na jej podstawie rozlokowanie stanowisk pomiarowych zgodnie z zasadą, że im bardziej złożona rzeźba terenu, tym więcej jest wymaganych stanowisk pomiarowych. Nie zawsze jednak możliwe jest takie usytuowanie stanowisk aby dokładnie zeskanować wszystkie elementy klifu. Najmniejsze zagęszczenie chmury punktów występuje zazwyczaj w obrębie jego korony. W celu uzupełnienia powstałych braków należałoby przeprowadzić skanowanie także $z$ pozycji zaplecza klifu lub z powierzchni stoku, oczywiście jeżeli pozwalają na to warunki lokalne. To jednak wiąże się $z$ dłuższym czasem pracy oraz zwiększoną kosztochłonnością pomiaru. $Z$ drugiej strony największe zagęszczenie punktów występuje $w$ najbliższym otoczeniu stanowisk pomiarowych oraz $\mathrm{w}$ obrębie najniższych partii klifów o dużym nachyleniu, czyli na powierzchniach, na które wiązka lasera pada pod największym kątem (maksymalnie 90 ${ }^{\circ}$ (ryc. 5). Średnia odległość między punktami chmury wynosi w rozpatrywanym przypadku zaledwie 0,013 m (tab. 1), co umożliwia stworzenie modelu o rozdzielczości $1,3 \mathrm{~cm}$. Rozdzielczość modelu nie powinna być wyższa niż błąd pomiaru, gdyż w takim przypadku może dojść do wygenerowania efektu szorstkości. Dla potrzeb monitoringu geomorfologicznego modele o tak wysokiej rozdzielczości nie są wymagane.

Kolejną techniką prezentowaną w niniejszym opracowaniu jest technika fotogrametryczna $S f M$ (ang. Structure from Motion), która w tym przypad$\mathrm{ku}$ opiera się na zdjęciach pozyskanych za pomocą bezzałogowego statku powietrznego, UAV-SfM. Metoda ta $\mathrm{w}$ ostatnich latach cieszy się bardzo dużym zainteresowaniem nie tylko $\mathrm{w}$ zakresie kartowania środowiska przyrodniczego, ale także $\mathrm{w}$ dokumentowaniu obiektów inżynierskich, architektonicznych, archeologicznych itd. (Westboy i in. 2012, Bolongesi $i$ in. 2015, Esposito i in. 2017). Polega ona na tworzeniu modelu trójwymiarowego (3D) z zestawu zdjęć w oparciu o obserwację i opis lokalizacji punktów na podstawie zmiany perspektywy, czyli lokalizacji stanowisk kamery. Metoda ta polega głównie na rozpoznawaniu punktów kluczowych na kilku wspólnych fotografiach i wyszukiwaniu zależności występującej między nimi na podstawie obserwacji zmian ich położenia (Chandler 1990, Snavely 2008, Westboy i in. 2012, Jankowicz 2014). Do przeprowadzenia takiego procesu wymagane są minimum trzy zdjęcia. W procesie przetwarzania obrazów 2D w model 3D możliwe jest uzyskanie gęstej chmury punktów, która w dużym stopniu przypomina chmury ze skanowania laserowego. Podstawową różnicą jest ilość informacji jaką posiada każdy punkt chmury. W przypadku SfM jest to tylko położenie przestrzenne punktów $\mathrm{XYZ}$ oraz ich barwa w modelu RGB, natomiast brak jest informacji jakie pozyskiwane są $\mathrm{w}$ procesie skanowania laserowego czyli: intensywności odbicia, numeru odbicia, liczby odbić, czy kierunku skanowania. Zasadniczym ograniczeniem tej techniki jest za- 
tem brak możliwości zbudowania cyfrowego modelu wysokościowego dla obszarów porośniętych gęstą roślinnością. Przetwarzanie zdjęć daje tylko możliwość uzyskania numerycznego modelu pokrycia terenu. Zastosowanie techniki UAV-SfM umożliwia za to stworzenie ortofotomozaiki. Wykorzystywane aktualnie $\mathrm{w}$ fotogrametrii specjalistyczne programy $\mathrm{w}$ dużej mierze automatyzują proces przetwarzania zdjęć, dzięki czemu w prosty sposób można odwzorować badany obiekt. W celu zwiększenia dokładności przestrzennej tworzonego modelu stosowana metodyka wymaga kalibracji położenia kamery. Proces ten odbywa się przy pomocy punktów kontroli naziemnej GCP. Polega on na rozplanowaniu w terenie odpowiedniej liczby punktów referencyjnych, których charakterystyka wizualna gwarantuje ich detekcję na zdjęciach. Położenie przestrzenne tych punktów (XYZ) określane jest za pomocą odbiornika GPS RTK, czyli aparatury dającej możliwość pomiaru z dokładnością ok. 20-30 mm.

W trakcie kartowania klifu za pomocą techniki $U A V$-SfM wykonano 279 zdjęć z pokryciem ok. 80\%. Fotografie wykonywane były na różnych pułapach oraz pod różnym kątem (zdjęcia pionowe i ukośne). Wynika to z założenia samej techniki SfM, w której dla określenia trójwymiarowej przestrzeni wymagane jest wykonanie wielu zdjęć pod różnymi kątami (Westboy $i$ in. 2012, Carrivick i in. 2016). W trakcie badań zobrazowana została powierzchnia klifu oraz plaży. Parametry nalotu umożliwiły stworzenie ortomozaiki o rozdzielczości $0,018 \mathrm{~m}$. W efekcie zastosowania techniki UAV-SfM zbudowana została chmura składająca się z 22170884 punktów. Średnie zagęszczenie chmury wyniosło 1033 pkt $\mathrm{m}^{-2}$, przy czym parametr ten charakteryzował się dość nierównomiernym rozłożeniem (ryc. 5, tab. 1). Najmniejsze zagęszczenie punktów zarejestrowano na powierzchni plaży, zaś największe na skłonie klifu, zwłaszcza w obrębie obiektów o dużym zróżnicowaniu morfologicznym (np. eksponowane ostrogi gliniaste, mikroformy rzeźby, czy roślinność niska i średnia). Liczba punktów oraz ich zagęszczenie warunkowane jest w tym przypadku przede wszystkim dokładnością zobrazowania obszaru. Liczba zdjęć, pułap z jakiego są wykonywane oraz ich wzajemne pokrycie warunkują ilość rozpoznanych punktów kluczowych, co z kolei przekłada się na gęstość wygenerowanej chmury punktów. W trakcie badań terenowych koncentrowano się głównie na obrazowaniu skłonu klifu, dlatego też ten element rzeźby został dokładniej sfotografowany (dla plaży wykonano mniejszą liczbę fotografii). Dzięki temu rozkład przestrzenny gęstości powierzchniowej chmury punktów ma charakter bimodalny (ryc. 5). Średni odstęp między punktami chmury wyniósł 0,029 m (tab. 1), co dało możliwość zbudowania numerycznego modelu pokrycia terenu o maksymalnej rozdzielczości $3 \mathrm{~cm}$. Model o tak wysokiej rozdziel- czości w monitoringu geomorfologicznym nie zawsze może być przydatny. Zastosowanie punktów kontroli naziemnej umożliwiło przeprowadzenie kalibracji kamery, co jest wymagane do optymalizacji modelu. W wyniku tego procesu średni błąd kwadratowy (RMSE) położenia punktów kontrolnych zawierał się $\mathrm{w}$ granicach $0,022-0,064 \mathrm{~m} \mathrm{z}$ wartością średnią wynoszącą $0,044 \mathrm{~m}$ (tab. 1). Uzyskany wynik jest w pełni zadowalający, gdyż wartością zbliża się do dokładności naziemnego skaningu laserowego $(0,014 \mathrm{~m})$.

\section{Możliwości i ograniczenia technik rejestracji zdalnej w kartowaniu wybrzeży klifowych}

Uzyskane wyniki wskazują, iż wszystkie z prezentowanych technik stanowią bardzo dobre źródło danych przestrzennych na temat ukształtowania wybrzeża. Z przeprowadzonej analizy wynika, iż każda $z$ nich posiada szereg zalet oraz pewne ograniczenia. Podstawowym aspektem branym pod uwagę $\mathrm{w}$ badaniach morfodynamiki wybrzeża jest dokładność zobrazowania terenu. Badacze, którzy zajmują się tym zagadnieniem zgodnie przyznają, iż technika naziemnego skaningu laserowego jest sposobem pozyskiwania danych o najwyższej jakości (Lichti, Licht 2006, Vosselman, Maas 2010, Soudarissanane i in. 2011, Westboy i in. 2012, Goodwin i in 2017, Klapa, Mitka 2017, Letortu i in. 2018, Medjkane i in. 2018). Błąd pomiaru dla skanera Leica Scanstation c10 wynosi $4 \mathrm{~mm} / 50 \mathrm{~m}$, a $\mathrm{w}$ przypadku pomierzonej chmury punktów wyniósł średnio $1,4 \mathrm{~cm}$. Taki rezultat daje doskonałe możliwości precyzyjnego szacowania bilansu osadów nadbrzeża. W przypadku techniki fotogrametrycznej SfM parametr ten wypadł nieco słabiej, tj. $4,5 \mathrm{~cm}$. Niemniej jednak dokładność rzędu kilku centymetrów umożliwia przeprowadzenie precyzyjnych analiz różnicowych. W przypadku tej techniki błąd pomiaru nie ma charakteru systematycznego jak ma to miejsce w przypadku TLS i trudno jest szacować jego wartość pomiędzy punktami referencyjnymi (GCP) (Westboy $\mathrm{i}$ in. 2012, Carrvick i in. 2016). $Z$ tego też względu dla optymalizacji niepewności pomiaru wymagane jest lokowanie $\mathrm{w}$ terenie jak największej liczby punktów kontroli naziemnej. Najmniejszą dokładnością charakteryzowały się dane ALS. W tym przypadku błąd położenia punktu wyniósł $0,2 \mathrm{~m}$, co dla danych uzyskanych tę techniką i tak jest wartością niewielką. Niemniej jednak prowadzenie analiz bilansowych mogłoby pociągać za sobą większą niepewność niż w przypadku technik TLS i UAV-SfM.

Bardzo ważnym parametrem warunkującym możliwości wykorzystania danych $\mathrm{w}$ monitoringu geomorfologicznym jest rozdzielczość przestrzenna zo- 
brazowania. W tym przypadku system TLS również ma najwięcej do zaoferowania. Pozyskanie chmury o gęstości 35634 pkt m ${ }^{-2}$ dało możliwość zbudowania modelu o rozdzielczości $14 \mathrm{~mm}$. Pojawia się jednak pytanie czy tak szczególowe obrazowanie jest potrzebne w monitoringu geomorfologicznym? $\mathrm{Z}$ pewnością tak, jeżeli badania dotyczą ewolucji niewielkich form terenu, natomiast $\mathrm{w}$ przypadku obserwacji kilkusetmetrowych odcinków wybrzeża tak duży stopień uszczegółowienia nie jest wymagany. Jedynym ograniczeniem techniki TLS w pomiarach klifów jest dość słabe odwzorowanie ich korony (jeżeli pomiar odbywa się tylko z plaży). O ile na klifach niskich problem nie jest duży, o tyle w przypadku wysokich klifów ten ważny element morfologiczny znajduje się zazwyczaj w martwym polu, szczególnie gdy w linii skanowania występuje roślinność. Wykorzystanie techniki $U A V$-SfM także umożliwiło pozyskanie bardzo gęstej chmury punktów (1033 pkt $\mathrm{m}^{-2}$ ). W efekcie możliwe było zbudowanie modelu o rozdzielczości $30 \mathrm{~mm}$. Model utworzony na podstawie cyfrowych fotografii zawsze będzie odwzorowywał pokrycie terenu, dlatego w monitorowaniu rzeźby najwyższą efektywność uzyskuje się na obszarach pozbawionych roślinności (np. aktywne klify lub plaża). Przewagą tej techniki nad skaningiem naziemnym jest możliwość równomiernego zobrazowania klifu. Wynika to $z$ faktu, iż technika UAV-SfM posiada możliwość ciągłej zmiany położenia i pozyskiwania obrazów z różnych wysokości i pod różnymi kątami. $Z$ kolei najrzadszą chmurę punktów uzyskano w wyniku skanowania lotniczego ALS. Średnia gęstość chmury dla analizowanego poligonu badawczego wyniosła $28 \mathrm{pkt} \mathrm{m}^{-2}$. Niemniej jednak dzięki takiemu zagęszczeniu punktów możliwe było utworzenie modelu o wielkości oczka siatki wynoszącego $17 \mathrm{~cm}$. Rozdzielczość taka nie daje możliwości analizowania mikrorzeźby, jednak $z$ powodzeniem może być podstawą dość szczegółowej charakterystyki parametrów morfometrycznych i morfologicznych większości form terenu występujących na klifie. Zróżnicowanie przestrzenne gęstości powierzchniowej chmury punktów jest w tym przypadku relatywnie niewielkie. Największa koncentracja punktów występuje na obszarach płaskich lub słabo nachylonych, zaś najmniejsza na powierzchniach o dużej inklinacji. Prawidłowość ta pociąga za sobą pewne ograniczenia w kartowaniu gliniastych klifów, charakteryzujących się dużymi spadkami. Analiza wykazała, iż $\mathrm{w}$ takich przypadkach gęstość chmury spadała nawet do 1-2 pkt $\mathrm{m}^{-2}$ (ryc. 5).

Kolejnym aspektem metodycznym dość istotnym w monitoringu geomorfologicznym jest rozdzielczość czasowa prowadzonych badań. Możliwość systematycznego kartowania powierzchni testowych w jak najkrótszych odcinkach czasowych jest bardzo korzystna z punktu widzenia badania sezonowej zmienności morfologicznej klifu. Na podstawie obserwacji powtarzanych $\mathrm{w}$ krótkich interwałach czasowych możliwe jest szczególowe określenie natury systemu denudacyjnego wybrzeży. Możliwość częstego kartowania warunkowana jest $\mathrm{w}$ dużej mierze czynnikami praktycznymi związanymi $z$ logistyką oraz czasem pracy, a także finansowymi, czyli kosztami wykonywanych pomiarów. W tym przypadku najkorzystniejszym rozwiązaniem jest wykorzystanie bezzałogowego statku powietrznego, gdyż generuje on najniższe koszty, zaś sam pomiar jest relatywnie krótki. Zasadniczym ograniczeniem wszystkich prezentowanych technik jest ich uzależnienie od warunków pogodowych. Zarówno naziemny jak i lotniczy skaning laserowy nie może być wykonywany w trakcie opadów atmosferycznych gdyż wiązki promieni są silnie pochłaniane przez wodę. Możliwość lotów dronem w takich warunkach jest również silnie ograniczona. Ponadto w przypadku dronów dużym ograniczeniem są porywiste wiatry, które często występują w morskiej strefie brzegowej.

Z powyższej analizy wynika, iż każda technika dostarcza danych o wysokiej jakości, które z powodzeniem można wykorzystywać $\mathrm{w}$ analizach rzeźby oraz jej zmian w czasie. Niemniej jednak każda z nich posiada pewne ograniczenia, które należy brać pod uwagę na etapie planowania badań. Wydaje się, że do szczegółowego kartowania niewielkich obszarów optymalnym rozwiązaniem jest naziemny skaning laserowy. Wynika to przede wszystkim z możliwości uzyskania dużej rozdzielczości oraz dokładności zobrazowania. Danych o podobnej jakości dostarcza również technika Structure from Motion, bazująca na zdjęciach wykonanych z drona UAV-SfM. Jednak jej zasadniczą wadą są ograniczenia $\mathrm{w}$ kartowaniu obszarów gęsto porośniętych roślinnością. Największe możliwości wykorzystania tej techniki w badaniu wybrzeży morskich upatruje się w kartowaniu plaż oraz aktywnych klifów pozbawionych roślinności. Największą zaletą tej techniki jest duża łatwość w wykonywaniu pomiarów oraz w opracowywaniu wyników. Zobrazowania o bardzo wysokiej rozdzielczości charakteryzują się bardzo dużą objętością. Do przetwarzania dużych plików wymagane są duże moce obliczeniowe. Ten problem nie ma większego znaczenia $\mathrm{w}$ przypadku danych $z$ lotniczego skaningu laserowego. $\mathrm{Z}$ uwagi na fakt, iż technika $A L S$ dostarcza informacji o mniejszej rozdzielczości najlepiej jest z niej korzystać $\mathrm{w}$ analizach większych obszarów. Ponadto możliwość uzyskania bezpłatnych danych z urzędów morskich dodatkowo zwiększa jej atrakcyjność.

\section{Wnioski}

W niniejszym artykule przedstawiona została ocena trzech technik rejestracji zdalnej wykorzystywanych 
w monitoringu geomorfologicznym wybrzeża klifowego wyspy Wolin. Analizie poddano podstawowe parametry danych lotniczego skanowania laserowego, naziemnego skanowania laserowego oraz techniki fotogrametrycznej Structure from Motion, bazującej na zdjęciach pozyskanych za pomocą drona (UAV-SfM). W toku analiz wykazano, iż zobrazowania o największej rozdzielczości i dokładności można uzyskać stosując techniki naziemnego skaningu laserowego oraz Structure from Motion. Dane o tak dużej szczegółowości najlepiej wykorzystuje się do analiz niewielkich poligonów badawczych. Dokładność rzędu kilku centymetrów umożliwia charakterystykę morfologiczną mikrorzeźby oraz prowadzenie precyzyjnych analiz transportu osadów w obrębie nadbrzeża. Dla dużych obszarów wskazane jest wykorzystanie danych z lotniczego skaningu laserowego (ALS), gdzie wysoki stopień uszczegółowienia mikro-reliefu nie jest konieczny. Tego typu dane doskonale nadają się do opisu zasadniczych założeń rzeźby oraz określania dynamiki dłuższych odcinków wybrzeża. Ponadto chmury punktów o relatywnie niewielkiej objętości łatwiej poddają się procesowi obróbki i nie wymagają stosowania sprzętu o wysokich mocach obliczeniowych.

Dane pozyskane za pomocą prezentowanych technik mogą być łączone $z$ wynikami innych metod kartowania środowiska takich jak np. wysokorozdzielcza batymetria podbrzeża pozyskana za pomocą echosondy wielowiązkowej. Integracja tych dwóch typów danych daje możliwość przeprowadzenia analizy bilansu osadów w całym profilu strefy brzegowej (nadbrzeże, plaża, podbrzeże), co jest tak ważne dla określenia tendencji rozwoju wybrzeży morskich.

\section{Podziękowania}

Podziękowania kieruję $\mathrm{w}$ stronę poznańskiej firmy Geocartis sp. z o.o. za wieloletnią współpracę w ramach realizacji naziemnego skaningu laserowego oraz Urzędu Morskiego w Szczecinie za udostępnienie danych $z$ lotniczego skaningu laserowego.

\section{Literatura}

Bęcek K., 2010. Adwent metod teledetekcji aktywnej do monitorowania zjawisk przyrodniczych. Acta Scientarium Polonorum Geodesia et Descriptio Terrarum 9(2): 3-20.

Bolognesi M., Furini A., Russo V., Pellegrinelli A., Russo P., 2015. Testing the low-cost rpas potential in 3D cultural heritage reconstruction. International Archives of the Photogrammetry, Remote Sensing and Spatial Information Sciences - ISPRS Archives 40: 229-235.

Borówka R.K., Gonera P., Kostrzewski A., Zwoliński Z., 1982. Origin age and paleogeographic significance of cover sands in the Wolin end moraine area, North-West Poland. Quaestiones Geographicae 8: 5-36.

Borówka R.K., Goslar T., Pazdur A., 1999. Wolińska morena czołowa: wiek struktur glacitektonicznych w świetle danych litostra- tygraficznych oraz datowań radiowęglowych. W: R.K.Borówka, Z.Młynarczyk, A.Wojciechowski (eds), Ewolucja geosystemów nadmorskich południowego Bałtyku, Bogucki Wydawnictwo Naukowe, Poznań-Szczecin.

Carrivick J.L., Smith M.W., Quincey D.J., 2016. Structure from Motion in the Geosciences. John Wiley \& Sons.

Chandler J.H., 1999. Effective application of automated digital photogrammetry for geomorphological research. Earth Surface Processes and Landforms 24: 51-63.

Dudzińska-Nowak J. 2017. Morphodynamic Processes of the Swina Gate Coastal Zone Development (Southern Baltic Sea). In: J.Harff, K.Furmańczyk, H.von Storch (eds) Coastline Changes of the Baltic Sea from South to East. Coastal Research Library 19. Springer, Cham. DOI: 10.1007/978-3-319-49894-2_11.

Dudzińska-Nowak J., Wężyk P., 2014. Volumetric changes of a soft cliff coast 2008-2012 based on DTM from airborne laser scanning (Wolin Island, southern Baltic Sea). In: A.N.Green, J.A.G.Cooper, (eds), Proceedings 13th International Coastal Symposium (Durban, South Africa), Journal of Coastal Research, Special Issue 70: 59-64.

Esposito G., Salvini R., Matano F., Sacchi M., Danzi M., Somma R., Troise C., 2017. Multitemporal monitoring of a coastal landslide through SfM-derived point cloud comparison. Photogrammetric Record 32: 459-479.

Frydel J., Mil L., Szafarin T., Koszka-Maroń D., Przyłucka M., 2017. Zmienność czasowa i zróżnicowanie przestrzenne wielkości i tempa erozji klifu Zatoki Usteckiej w rejonie Orzechowa. Landform Analysis 34: 3-14. DOI: 10.12657/landfana-034-001.

Głowienka E., Jankowicz B., Kwoczyńska B., Kuras P., Michałowska K., Mikrut S., Moskal A., Piech I., Strach M., Sroka J., 2015. Fotogrametria i skaning laserowy w modelowaniu 3D. W: S.Mikruta, E.Głowienka (red), Wyższa Szkoła Inżynieryjno-Ekonomiczna w Rzeszowie.

Gomes Pereira L.M., Wicherson R.J., 1999. Suitability of laser data for deriving geographical information - a case study in the context of management of fluvial zones. ISPRS Journal of Photogrammetry and Remote Sensing 54: 105-114.

Goodwin N.R., Armston J.D., Muir J., Stiller I., 2017. Monitoring gully change: A comparison of airborne and terrestrial laser scanning using a case study from Aratula, Queensland. Geomorphology 282: 195-208. DOI: 10.1016/j.geomorph.2017.01.001.

Hug Ch., Wehr A., 1997. Detecting and Identifying Topographic Objects in Imaging Laser Altimeter Data. International Archives of Photogrammetry and Remote Sensing 32(3-4): 19-26.

Jankowicz B., 2014. Wielkoseryjne obrazy niskopułapowe w modelowaniu 3D dla analiz przestrzennych terenu. Wydawnictwo Uniwersytetu Rolniczego w Krakowie: 43-46.

Klapa P., Mitka B., 2017. Application of terrestrial laser scanning to the development and updating of the base map. Geodesy and Cartography 66(1): 59-72. DOI: 10.1515/geocart-2017-0002.

Kolander R., Morche D., Bimböse M., 2013. Quantification of moraine cliff coast erosion on Wolin Island (Baltic Sea, northwest Poland). Baltica 26(1): 37-44.

Kostrzewski A., 1985. Variations in the particle-size distribution and degree of sand grain abrasion in morainic till of the Wolin island, NW Poland. Quarternary Stuides in Poland 6: 83-97.

Kostrzewski A., Zwoliński Zb., 1986. Operation and morphologic effects of present-day morphogenetics processes modelling the cliffed coast of Wolin Island, N.W. Poland. In: V.Gardiner (eds), International Geomorphology 1986 Pt 1, John Wiley and Sons: $1231-1252$.

Kostrzewski A., Zwoliński Zb., 1994a. Contemporary morphodynamics of the cliff coasts of Wolin Island. In: K.Rotnicki (eds), Changes of the Polish Coastal Zone, QRI, AMU, Poznań: 145155.

Kostrzewski A., Zwoliński Zb., 1994b. Bałtyckie wybrzeże klifowe Wyspy Wolin - stan aktualny, tendencje rozwoju. Klify 1: 81-97.

Kostrzewski A., Zwoliński Zb., 1995. Present-day morphodynamics of the cliff coasts of Wolin Island. Journal of Coastal Research, Spec. Iss. 22: 293-303. 
Kostrzewski A., Zwoliński Zb., Winowski M., Tylkowski J., Samołyk M., 2015. Cliff top recession rate and cliff hazards for the sea coast of Wolin Island (Southern Baltic). Baltica: 28: 109120. DOI: 10.5200/baltica.2015.28.10, 2015.

Kurczyński Z., 2014. Lotnicze skanowanie laserowe - podstawy teoretyczne. W: P.Wężyk (red), Podręcznik dla uczestników szkoleń z wykorzystania produktów LiDAR, Główny Urząd Geodezji i Kartografii, Warszawa: 59-109.

Letortu P., Jaud M., Grandjean P., Ammann J., Costa S., Maquaire O., Davidson R., Le Dantec N., Delacourt C., 2018. Examining high-resolution survey methods for monitoring cliff erosion at an operational scale. GIScience \& Remote Sensing 55: 457-476.

Lichti D.D., Licht M.G., 2006. Experiences with terrestrial laser scanner modelling and accuracy assessment. The International Archives of the Photogrammetry, Remote Sensing and Spatial Information Sciences 36(5): 155-160.

Liu X., Zhang Z., Peterson J., Chandra S., 2007. The effect of LiDAR data density on DEM accuracy. In Proceedings of International Congress on Modelling and Simulation (MODSIM07), Christchurch, New Zealand: 1363-1369.

McCullagh M.J., 1988. Terrain and surface modelling systems: theory and practice. Photogrammetric Record 12(72): 747-779.

Medjkane M., Maquaire O., Costa S., Roulland T., Letortu P., Fauchard C., Antoine R., Davidson R., 2018. High-resolution monitoring of complex coastal morphology changes: cross-efficiency of SfM and TLS-based survey (Vaches-Noires cliffs, Normandy, France). Landslides 15(6): 1097-1108. DOI: 10.1007/s10346017-0942-4.

Reutebuch S.E., McGaughey R.J., Andersen H.-E., Carson W.W., 2003. Accuracy of a high-resolution LIDAR terrain model under a conifer forest canopy. Canadian Journal of Remote Sensing 29(5): 527-53.

Snavely N., 2008. Scene reconstruction and visualization from Internet photo collections. Unpubl. PhD thesis, University of Washington, USA.

Soudarissanane S., Lindenbergh R., Menenti M., Teunissen P., 2011. Scanning geometry: Influencing factor on the quality of terrestrial laser scanning points. ISPRS Journal of Photogrammetry and Remote Sensing 66(4): 389-399. DOI: 10.1016/j. isprsjprs.2011.01.005.

Stereńczak K., 2009. Lotniczy skaning laserowy (LiDAR) w badaniach na rzecz ochrony przyrody. Studia i Materiały Centrum Edukacji Przyrodniczo-Leśnej 11(2): 135-143.

Terefenko P., Giza A., Paprotny D., Kubicki A., Winowski M., 2018. Cliff retreat induced by series of storms at Międzyzdroje (Poland). Journal of Coastal Research 85: 181-185.

Terefenko P., Paprotny D., Giza A., Morales-Nápoles O., Kubicki A., Walczakiewicz S., 2019. Monitoring Cliff Erosion with LiDAR Surveys and Bayesian Network-based Data Analysis. Remote Sensing 11: 843.

Uścinowicz G., Szarafin T., Jurys L., 2019. Tracking cliff activity based on multi temporal digital terrain models-an example from the southern Baltic Sea coast. Baltica 32: 10-21.

Vosselman G., Maas H.-G., 2010. Airborne and Terrestrial Laser Scanning. Taylor \& Francis, CRC Press, Boca Raton.

Westoby M., Brasington J., Glasser N., Hambrey M., Reynolds J., 2012. 'Structure-from-Motion' photogrammetry: A low-cost, effective tool for geoscience applications. Geomorphology 179(1): 300-314.

Wężyk P. (red.), 2015. Podręcznik dla uczestników szkoleń z wykorzystania produktów LiDAR. Główny Urząd Geodezji i Kartografii, Warszawa.

Wężyk P., 2006. Wprowadzenie do technologii skaningu laserowego w leśnictwie. Roczniki Geomatyki 4(4): 119-132.

Winowski M., Kostrzewski A., Tylkowski J., Zwoliński Z., 2019. The importance of extreme processes in the development of the Wolin Island cliffs coast (Pomeranian Bay - Southern Baltic). In: Proceedings, International Scientific Symposium New Trends in Geography, Macedonian Geographical Society, Ohrid: 99-108.

Winowski M., Śramski M., 2017. Ocena ilościowa zmian rzeźby klifu w świetle pomiarów z naziemnego skaningu laserowego (Wyspa Wolin). W: A.Kostrzewski, M.Winowski (red.), Geoekosystem Wybrzeży Morskich 3: 45-55. 